\title{
FAUNAL DYNAMICS IN THE ŽELEZNA JAMA CAVE
}

\author{
DINAMIKA FAVNE V ŽELEZNI JAMI
}

TONE NOVAK ${ }^{1} \&$ JOŽICA SAMBOL ${ }^{2} \&$ FRANC JANŽEKOVIČ ${ }^{1}$

${ }^{1}$ Department of Biology, University of Maribor, Koroška 160, SI-2000 MARIBOR, SLOVENIA, e-mails: tone.novak@uni-mb.si; franc.janzekovic@uni-mb.si

2 jozica.sambol@guest.arnes.si 


\section{Tone Novak \& Jožica Sambol \& Franc Janžekovič: Faunal dynamics in the Železna jama cave}

In 2000-2001, the fauna of and ecological conditions in the Železna jama cave near Dob in the isolated karst area of Domžale-Moravče (east of the town of Domžale, central Slovenia), were investigated. Fifty-three species were found in the cave, the dominant ones being Meta menardi, Amilenus auriantiacus, Troglophilus neglectus, T. cavicola, Laemosthenes schreibersi, Ceuthmonocharis robici, Limonia nubeculosa and an undetermined phorid species. The troglomorphotic taxa found were: Zospeum sp., C. robici, Anophthalmus sp. among others. Besides seasonal changes in the local and the cave climate, changes in drought intensity and the varying quantities of organic matter in the substrate were probably the most important factors triggering migrations. Animals migrated between the cave and the surface, adjacent fissure systems and the water channel in the bottom of the cave, which is inaccessible to humans.

Key words: ecology, migrations, subterranean habitats, subterranean fauna, troglomorphosis, Železna jama cave.

Izvleček

UDK: 551.44:591.542(497.4)

\section{Tone Novak \& Jožica Sambol \& Franc Janžekovič: Dinamika favne v Železni jami}

V letih 2000-2001 smo raziskovali favno in ekološke razmere v Železni jami pri Dobu. V jami smo našli 53 vrst, dominantne so bile: Meta menardi, Amilenus auriantiacus, Troglophilus neglectus, T. cavicola, Laemosthenes schreibersi, Ceuthmonocharis robici, Limonia nubeculosa in nedoločena vrsta foride. Troglomorfozni taksoni so bili Zospeum sp., C. robici, Anophthalmus sp. in nekateri drugi. Poleg sezonskih sprememb v lokalni klimi in klimi jame so spremembe jakosti prepiha ter količina organskih snovi v substratu v posameznih delih jame verjetno poglavitni vzroki za intenzivne migracije favne. Živali so migrirale med jamo ter površjem, sistemi špranj ob jami in vodnim rovom ob dnu jame.

Ključne besede: ekologija, migracije, podzemeljski habitati, podzemeljska favna, troglomorfoza, Železna jama. 


\section{INTRODUCTION}

In Slovenia, about $43 \%$ of the territory consists of limestone (Gams, 1974), mostly accompanied by karstic phenomena. Small limestone patches of up to a few dozen square kilometres are called isolated karst, one of which is the Domžale-Moravče isolated karst (Habe, 1972; Stražar, 1979) in Central Slovenia. The Železna jama cave (Fig. 1) is the most visited cave in the region, as, since 1963 it has been functioning as a tourist venue (Stražar, 1996). The cave is situated in Cretaceous shell limestone (Rakovec, 1955). When discovered, it was accessible through a pothole opening into a horizontal passage. Subsequently, an artificial entrance was dug to allow tourist visits (Gams, 1972). The cave is about $70 \mathrm{~m}$ long and $20 \mathrm{~m}$ deep. Morphologically, it can be divided into four parts: the entrance passage, two halls (the Prva- and the Druga dvorana) which originated as potholes (Gams, 1972), and the end part, accessible through an artificially enlarged passage way. The limestone walls and ceiling are mostly bare, partly bituminous, and in some parts of the cave covered with flowstone. The bottom consisted originally of gravel and clay; however the pathway was later partly paved with concrete. At the bottom, the cave communicates with a water passage inaccessible to humans, which floods the lower part of the cave during heavy rains (Gams, 1972).

Following the discovery of the first eyeless beetle in the world, Leptodirus hochenwartii, in 1832 in the Postojnska jama cave by Ferdinand Josef Schmidt, interest in discovering hypogean fauna was greatly increased in other karst regions. Most of our knowledge about the fauna of the Železna jama and other caves in the Domžale-Moravče isolated karst had been provided by sporadic observations and by collecting of selected taxa. Schmidt himself, at that time the curator in the Museum of Natural History in Ljubljana, explored caves in "Krain" (a region comprising most of present-day Slovenia) including eight caves in the vicinity of Domžale and Moravče (Kiauta, 1961). In the Dolga jama cave, he discovered Ceuthmonocharis freyeri, the first hypogean beetle species from the region, described by L. Miller in 1855 (sub Adelops), and in the Dolga cerkev cave near Zgornja Javorščica, Anophtalmus schaumi schaumi was found. In 1858, Henrik Hauffen published a few contributions to the knowledge of caves in Slovenia with some malacological notes, partly dealing with the caves in the region (Kiauta, 1961). Robič (1862) provided the first systematic review of the fauna in caves of the Domžale-Moravče isolated karst. He collected a lot of avertebrates in caves, especially beetles (Kos, 1925; Bohinec, 1972). Schmidt (1866) noted some findings of the cave crickets Troglophilus. Simon Robič, the priest, and his sexton Ivan Sešek were zealous collectors of this fauna. In 1898, Sešek was familiar with 27 caves in the region, including the Krumperška sapnica cave, today's Železna jama cave (Stražar, 1996). Subsequently, further hypogean species from caves in this region were described. Another eyeless beetle, Ceuthmonocharis r. robici (Ganglbauer, 1899), was named in honour of Robič. Gustav Joseph $(1868,1881,1882)$ dealt intensely with arthropods and described several new species from the caves. Later on, C. robici staudacheri (J. Müller, 1919) and C. pusillus (Jeannel, 1924) were described. Other eyeless beetles also live in the region (Drovenik, 1972), such as the leptoditins Bathyscia m. montana and B. m. forticornis, the latter described from the Celarjeva jama cave near Moravče. The carabid beetles Anophtalmus s. schaumi and A. micklitzi fallaciosus are endemic to the region. Laemosthenes (Antisphodrus) schreibersi is a common troglophile carabid in the caves. The curculionid Troglorrhynchus anophthalmus and the staphylinid beetle Glyptomerus cavicola have been recorded, too. Both cave crickets living in Slovenia, Troglophilus cavicola and T. neglectus, are common in caves of the Domžale-Moravče karst (Wolf, 1934-38). Troglophilus cavicola was noted by Us (1970) in the Jama v Lepi dolini cave, and T. neglectus in 
the Železna jama cave.

The linyphiid spider Troglohyphantes polyopthalmus, descovered in Železna jama by Joseph (1882), was subsequently found in other caves in the region (Deeleman-Reinhold, 1978). Jovan Hadži (1930) described the pseudoscorpion Chthonius raridentatus based on (among other evidence) material from the Boštonova jama cave near the village of Zalog (Beier, 1939). Most findings before the Second World War were uncritically compiled by Wolf (1934-38), such as a pseudoscorpionid species reported in the Ihanščica cave (sub Neobisium brevipes; this species does not live in Slovenia and Italy - Gardini, in lit.). In Lovrišnikova jama near Zgornje Koseze and in the Dolga jama caves, Trachysphaera costata has been found (Wolf, 1934-38, sub Gervaisia).

In the second half of the 20th century, Egon Pretner (1959), Jože Bole (1972, 1974), and others investigated the hypogean fauna of the Domžale-Moravče isolated karst (Drovenik, 1972). Some new species were described from the region. Among snails, six Zospeum species live in caves in this region: Z. isselianum (in Bole, 1974, sub Z. alpestre isselianum), Z. amoenum, Z. frauenfeldi, Z. kusceri, Z. lautum and Z. spelaeum schmidti, the first and the last of these have also been recorded for Železna jama cave (Bole, 1974).

Zoogeographically, the fauna from the Železna jama cave can generally be classified in two groups: the entrance- (the threshold-) fauna, consisting of common (middle-) European species, and the hypogean taxa, most of which are endemic to the (north-western) Dinaric karst or to the Moravče-Domžale isolated karst.

In accordance with a classical speleobiological approach (Vandel, 1964, Ginet \& Decou, 1977), three groups of species are discussed. The trogloxenes are epigean taxa, that inhabit the entrance parts of caves, and occasionally appear in caves. Their most important group consists of taxa belonging to the entrance- (= threshold-) fauna, which mostly overwinter or oversummer underground. The troglophiles inhabit mostly hypogean habitats in between the entrance and the inner sections, and are characterized by morphological, physiological and/or ecological adaptations to hypogean environments, e. g. by maturation during their overwintering there. The troglobites are subterranean taxa, living mostly in the inner sections, recognisable by their morphological and ecophysiological adaptations to the hypogean habitats. This general scheme is regularly disturbed by migratory activities: trogloxenes (e. g. lumbricids, Trogulus) can be found in the inner, and troglobites in the entrance areas of caves (e. g. Leptodirus even in direct sunshine).

Species richness is the most widely used measure of diversity (Lande, 1996), and also convenient for analysing differences between the parts of the cave.

Untill 2000, ecological investigations were lacking for caves in the Domžale-Moravče isolated karst (Sambol \& Novak, 2001). In this contribution our goal was to deal with selected ecological aspects of the Železna jama cave. The specific cave morphology allowed us to study the impact of both types of entrances - accessible and non-accessible to humans, as well as the cave-adjacent hypogean habitats, on local biotic diversity in various parts of the cave.

\section{MATERIAL AND METHODS}

In the years 2000-2001, ecological investigations were carried out in the Železna jama cave, visited each season twice within 48 hours. The cave was divided in 14 sections, the numbered points indicate the locations of sampling sites (Fig. 1; the first site was in front of the cave). The following 
parameters were measured at these locations: the distance of the individual placements from the entrance and the surface (accuracy: $1 \mathrm{~m}$ ), passage transection size $\left(1 \mathrm{~m}^{2}\right)$, air and ground temperature, T $\left(0.1^{\circ} \mathrm{C}\right)$, psychrometric air humidity, HR $(1 \%)$, ground hydricity, HY $(0.1 \%)$, and draught (measurements of fog or smoke movements; $0.1 \mathrm{~m} / \mathrm{s}$ ). The fauna were investigated by systematic observations of the cave walls and ceiling up to a height of $5 \mathrm{~m}$, by baited pitfall traps (decomposing beef hung above a mixture of juice and detergent), and by desiccation of ground materials by a modified Tullgren method. Additionally, mouse traps with sardine-oatmeal bait were placed at the entrance (the site 2), in the middle (6), and on the bottom of the cave (13).

Dominance and biotic diversity were tested by calculations of Simpson, $\mathrm{D}=\Sigma(\mathrm{Ni} / \mathrm{N})^{2}$, and Shannon-Wiener, $\mathrm{H}^{\top}=-\Sigma(\mathrm{Ni} / \mathrm{N}) * \ln (\mathrm{Ni} / \mathrm{N})$, indexes, respectively, where

$\mathrm{Ni}$ the number of individuals of a species,

$\mathrm{N}$ the total number of specimens.

H`was calculated using concrete data, and a hypothetical H`max was determined using the aver-

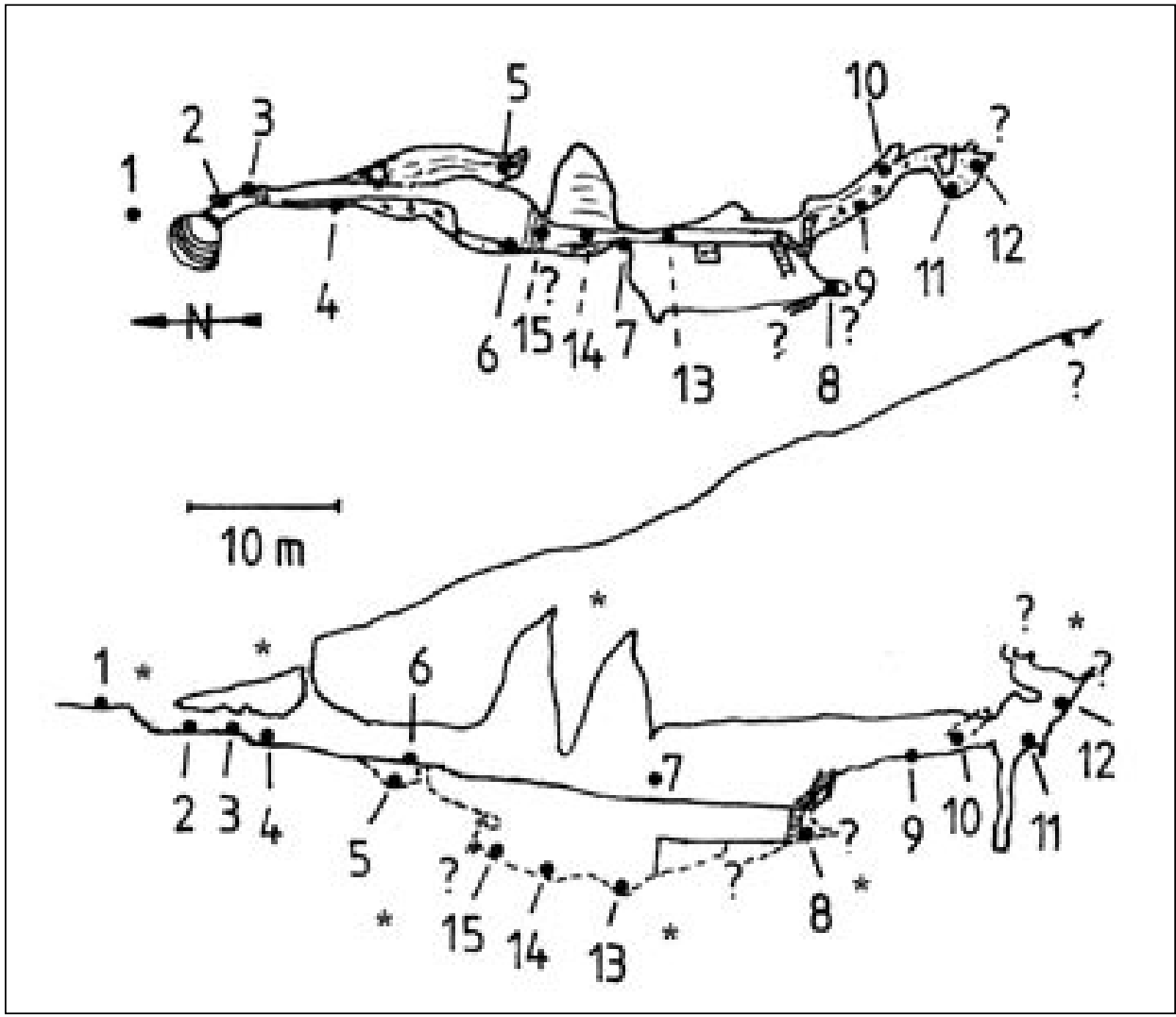

Fig. 1: The Železna jama cave (acc. to GAMS, 1972, partly modified; Sampling sites 1-15 represent the centroids of the sampling sections, * migratory routes).

Sl. 1: Železna jama (po GAMSU, 1972, deloma prirejeno; vzorčna mesta 1-15 so centroidi vzorčevalnih območij, * migracijske poti). 
age $\mathrm{Ni}$ at a site. The actual $\mathrm{H}^{`}$ were calculated as $\%$ of $\mathrm{H}^{`}$ in comparison with the $\mathrm{H}^{\prime}$ max.

Correlations between the distances of the cave's sampling sections from outside habitats, and H`, H`max, and D were calculated using Pearson's correlation coefficient.

Migratory- and non-migratory cave sections (Fig. 1) were determined according to the cave morphology, being entrances, chimneys presumably open to the surface, and cave sections close to the inaccessible water channel. Seasonal differences between migratory- and non-migratory cave sections, and diversity indexes H`, H'max and D, were tested using the LSD one-way ANOVA (the F test).

The invertebrate biomass per $\mathrm{m}^{2}$ was calculated using approximate data for the individual mass and energy content of each species present (Novak \& Kuštor, 1982, and unpublished data). To make comparisons between seasons appropriate, the data on vertebrates, present sporadically, were excluded.

\section{RESULTS}

The Železna jama is a dry, relatively warm cave with both an entrance (daylight, influence from outside circumstances) and an inner section (total darkness, no outside influences) (Figs. 2-4). In the warm part of the year, the whole cave is anemostatic, while in other seasons its entrance sections are anemodynamic, especially in winter time.

\section{Faunal review}

During intensive investigations in 2000-2001, 3093 specimens of the following 53 species were recorded in the Železna jama cave (List 1), and 11 further ones were found in front of the cave. Altogether, 3396 specimens belonging to 64 species were recorded during the investigation.

In front of the cave, the epigean species Limax cinereoniger, Paranemastoma quadripunctatum, Trogulus neapeformis, T. tingiformis and some other species were found, all of which appear sporadically in caves.

\section{Coenoses' analysis}

In the Železna jama cave, according to their origin, two coenotic groups can be distinguished: the entrance- (the threshold-) fauna and the hypogean fauna. The threshold fauna consisted of (middle) European species, common in the caves of (middle) Europe. As the dominant taxa in the cave, those appearing in numbers of 50 or more were taken into account. Of these, Meta menardi, Amilenus aurantiacus, Troglophilus cavicola, T. neglectus, Laemosthenes schreibersi (Figs. 6-10) and Limonia nubeculosa (Fig. 12) were recorded in the cave. Ceuthmonocharis r. robici (Fig. 11) is a dominant representative of the indigenous hypogean fauna in the region. The individuals of selected species as well as the entire fauna were unequally dispersed in the cave (Fig. 5). In this study we do not deal with the autecological aspects of species.

In terms of classical biospeological classifications, all three groups were found. The following taxa from the category of the trogloxenes have been recorded: the snails Limax cinereoniger and Campylaea planospira illyrica, an unidentified lumbricid species, the spiders Meta menardi, Metellina merianae, Nesticus cellulanus, Pholcus phalangioides and Tegenaria sp., the opilionid Leiobonum rupestre, Mesostigmata mites, the diplopods Trachysphaera costata, Polydesmus sp. and an iulid species, a podurid springtail, a machilid species, the caddis fly Stenophylax sp., the hymenopteran 


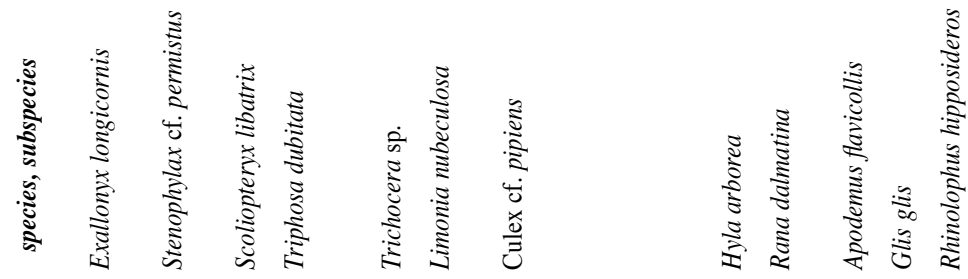

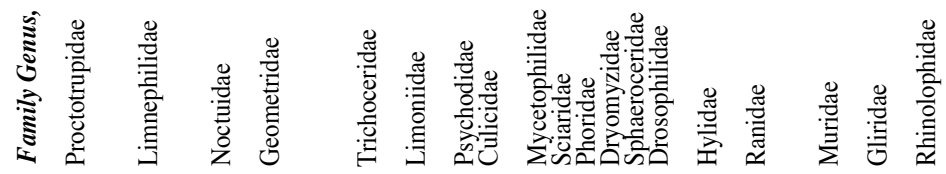

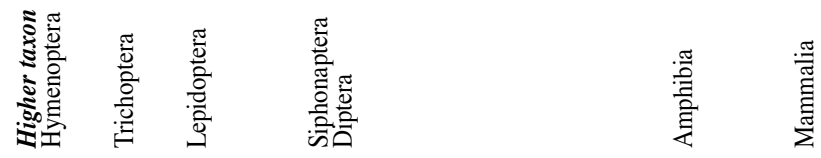

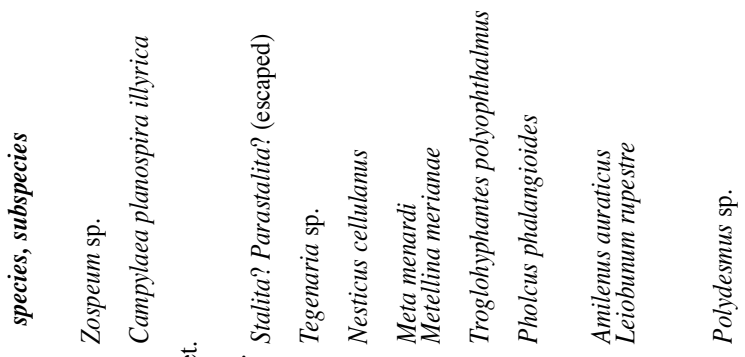

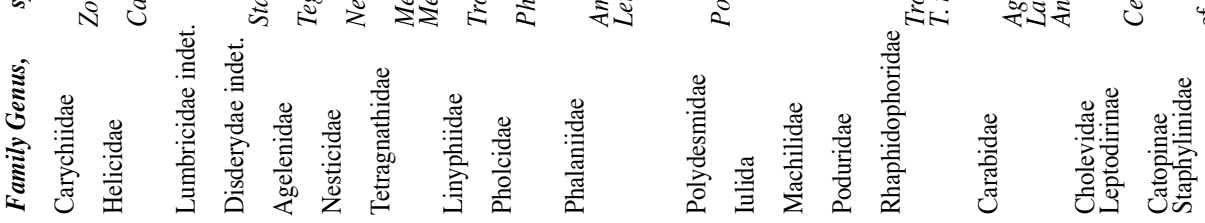

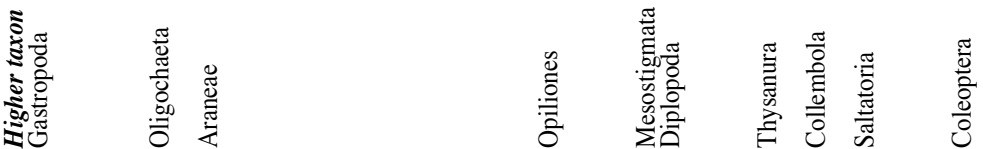

List 1: Review of fauna, recorded in Železna jama cave in 2000-2001. 


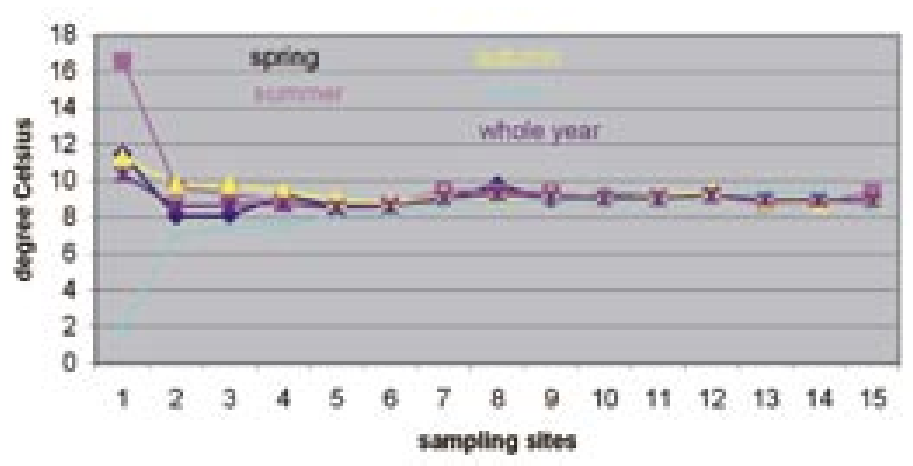

Fig. 2: Ground temperature in the Železna jama cave and in front of it, 2000-2001. Sl. 2: Temperatura tal $v$ Železni jami in pred njo, 2000-2001.

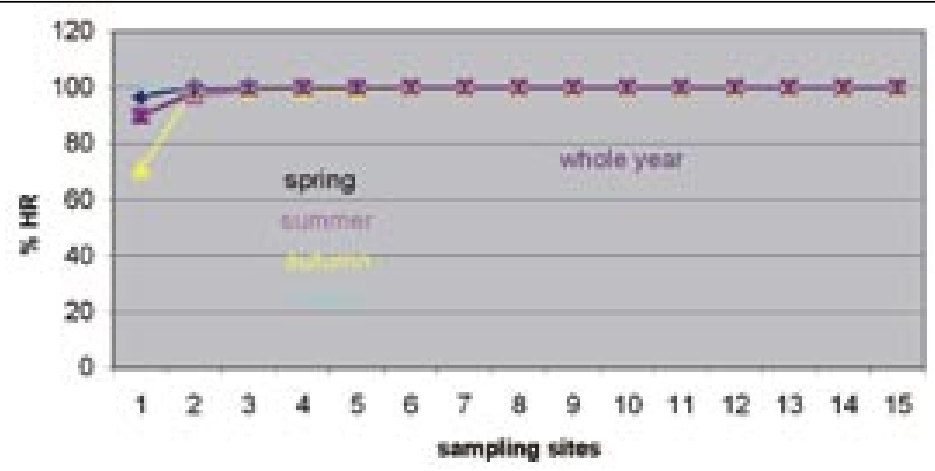

Fig. 3: Air humidity, HR, in the Železna jama cave and in front of it, 2000-2001. Sl. 3: Zračna vlaga v Železni jami in pred njo, 2000-2001.

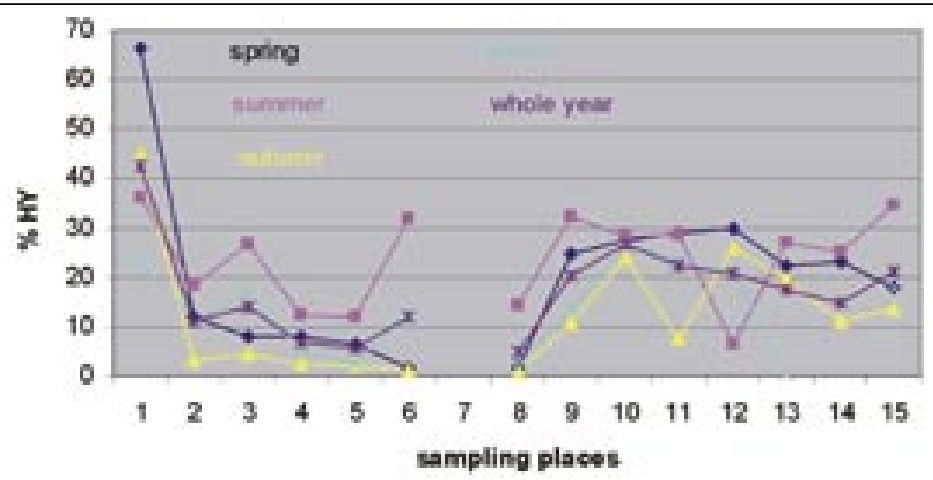

Fig. 4: Ground hygricity, HY, in the Železna jama cave and in front of it, 2000-2001 (point 7 - no sampling substrate present).

Sl. 4: Talna vlaga v Železni jami in pred njo, 2000-2001 (na 7. vzorčevalnem mestu ni ustreznega substrata). 
Exallonyx longicornis, the butterflies Scolyopterix libatrix and Triphosa dubitata, and dipterans Trichocera sp., Limonia nubeculosa, Culex pipiens and single species of the families Mycethophilidae, Psychodidae, Sciaridae, Dryomyzidae, Sphaeroceridae, Drosophilidae and probably the phorid species (Fig. 13). In winter, one Hyla arborea, two juvenile Rana dalmatina and the hygrophilous carabid beetle Agonum scrobiculatum entered the cave from the inaccessible water passage at the bottom of the cave. The amphibians obviously overwinter there. Rhinolophus hipposideros is the most common bat species in Slovenian caves, and has been recorded sporadically in this cave. The Železna jama cave is also used by the edible dormice (Glis glis). Besides scratches on argillaceous wall deposits, its fresh droppings were found in the cave from April till October. In autumn, Apodemus flavicollis frequented the entrance parts of the cave.

The following taxa were recognized to be troglophiles: a springtail species, the spider Troglohyphantes polyophthalmus, the opilionid Amilenus aurantiacus, a lithobiid species, the cave crickets Troglophilus cavicola and T. neglectus, the beetles Laemosthenes (Antisphodrus) schreibersi, Atheta

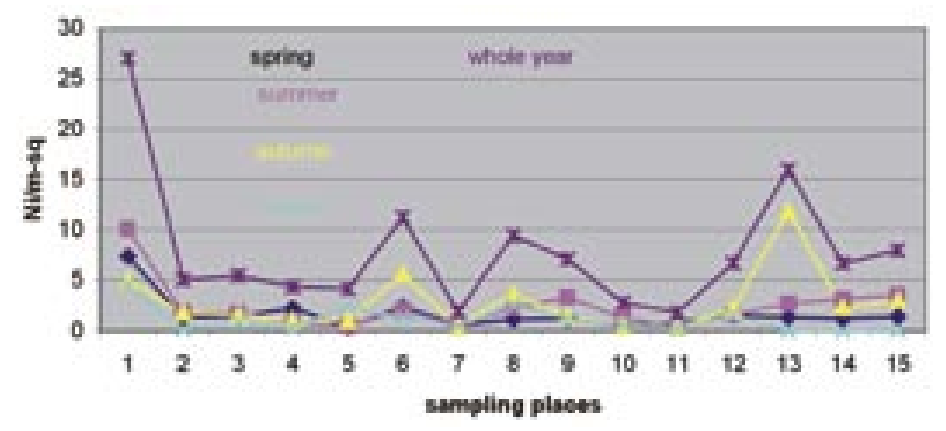

Fig. 5: Total number of individuals per $m^{2}$ in the Železna jama cave and in front of it, 2001-2002. Sl. 5: Skupno število osebkov/m2 v Železni jami in pred njo, 2000-2001.

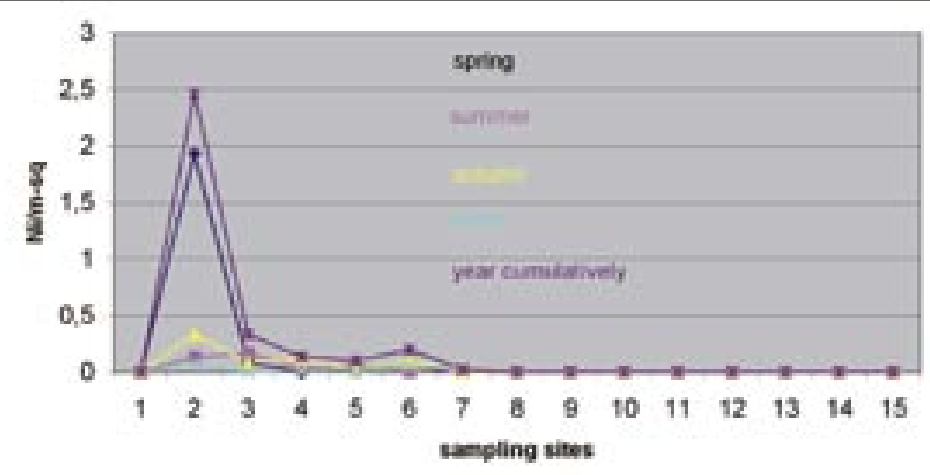

Fig. 6: The dispersion of Meta menardi per $m 2$ in the Železna jama cave, 2000-2001. Sl. 6: Razporeditev osebkov Meta menardi v Železni jami in pred njo, 2000-2001. 


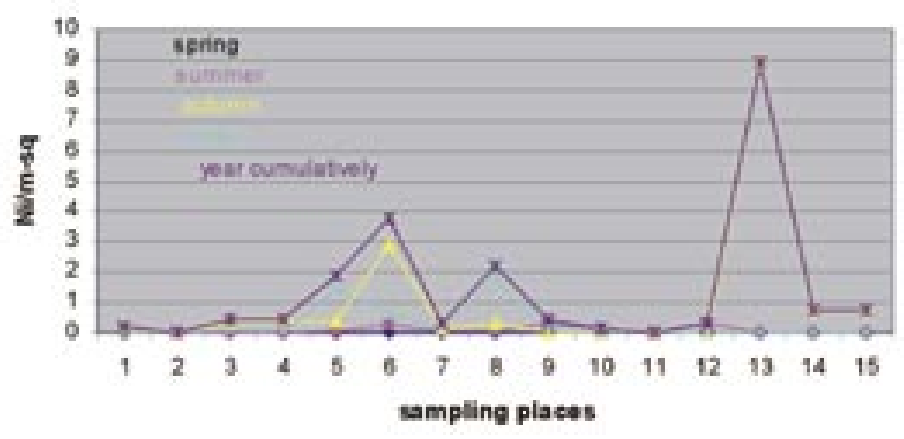

Fig. 7: The dispersion of Amilenus aurantiacus per $m^{2}$ in the Železna jama cave, 2000-2001. Sl. 7: Razporeditev osebkov Amilenus aurantiacus v Železni jami in pred njo, 2000-2001.

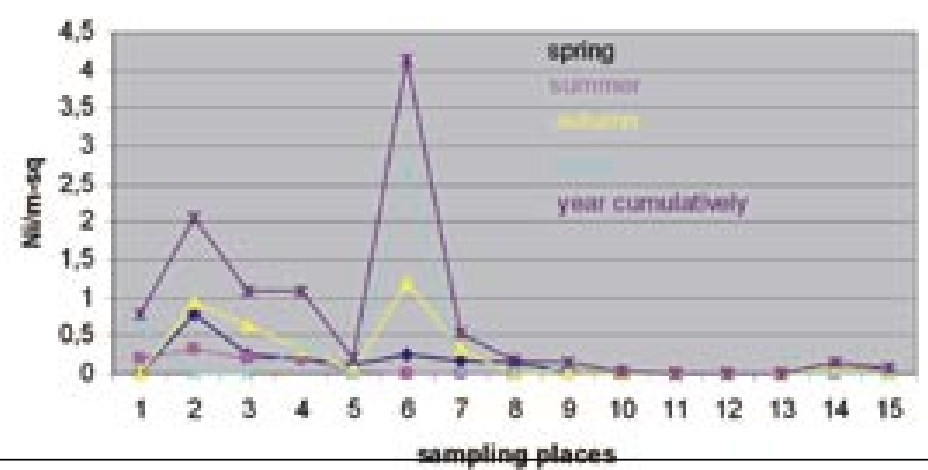

Fig. 8: The dispersion of Troglophilus neglectus per $m^{2}$ in the Železna jama cave, 2000-2001. Sl. 8: Razporeditev osebkov Troglophilus neglectus v Železni jami in pred njo, 2000-2001.

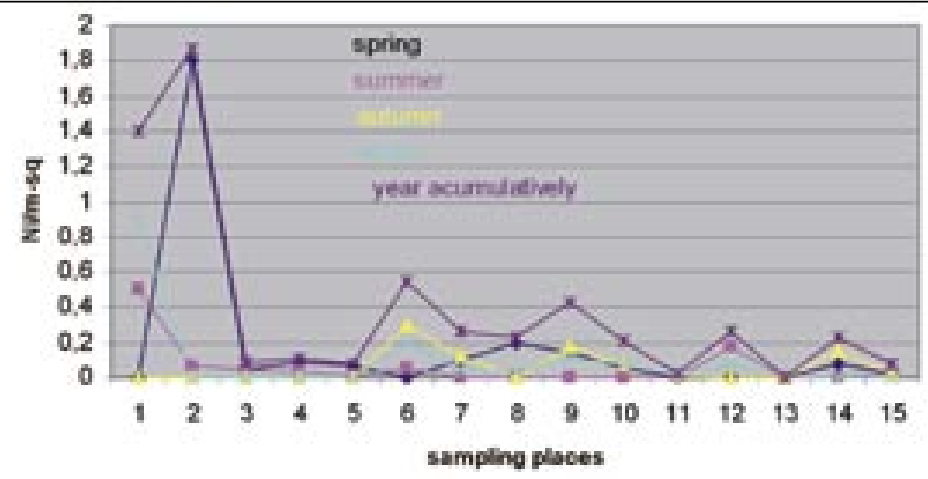

Fig. 9: The dispersion of Troglophilus cavicola per $m^{2}$ in the Železna jama cave, 2000-2001. Sl. 9: Razporeditev osebkov Troglophilus cavicola v Železni jami in pred njo, 2000-2001. 
Tone Novak \& Jožica Sambol \& Franc Janžekovič: Faunal dynamics in the Železna jama cave

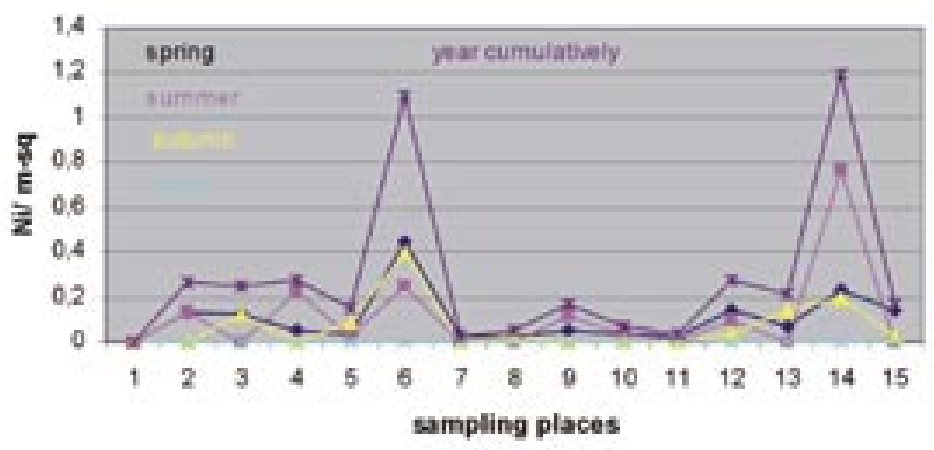

Fig. 10: The dispersion of Laemosthenes (Antisphodrus) schreibersi per $m^{2}$ in the Železna jama cave, 2000-2001.

Sl. 10: Razporeditev osebkov Laemosthenes (Antisphodrus) schreibersi v Železni jami in pred njo, 2000-2001.

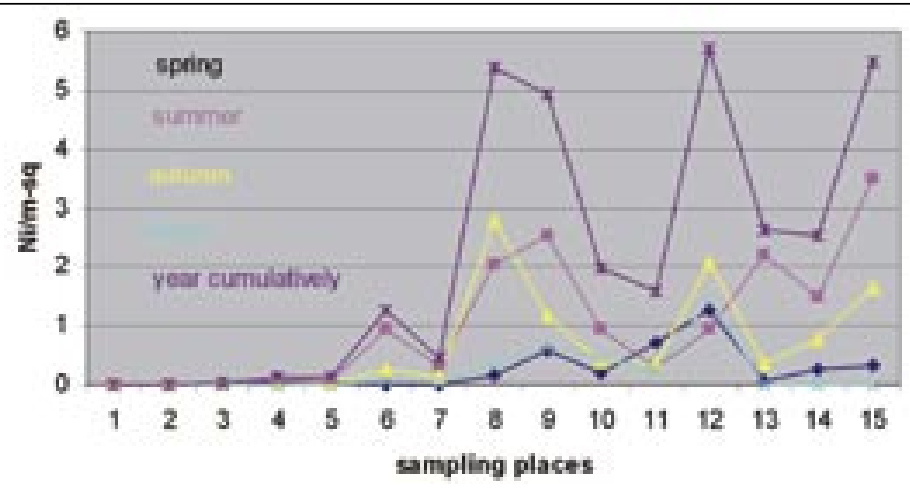

Fig. 11: The dispersion of Ceuthmonocharis robici per $m^{2}$ in the Železna jama cave, 2000-2001. Sl. 11: Razporeditev osebkov Ceuthmonocharis robici v Železni jami in pred njo, 2000-2001.

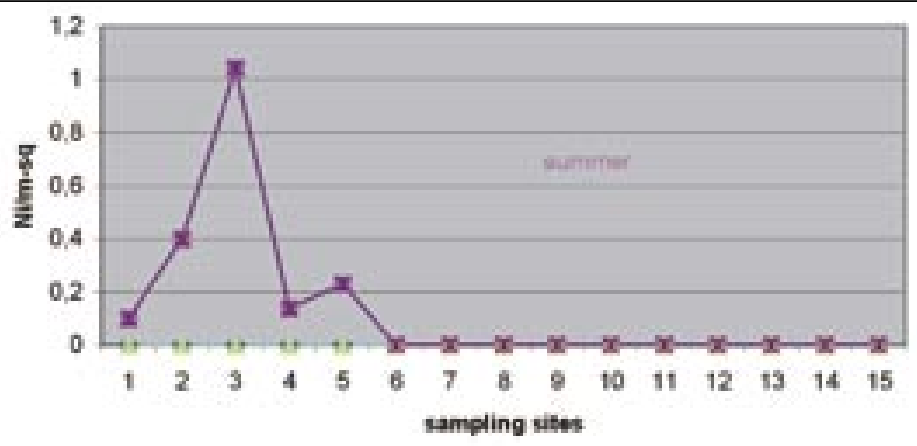

Fig. 12: The dispersion of Limonia nubeculosa per $m^{2}$ in the Železna jama cave, 2000-2001. Sl. 12: Razporeditev osebkov Limonia nubeculosa v Železni jami in pred njo, 2000-2001. 


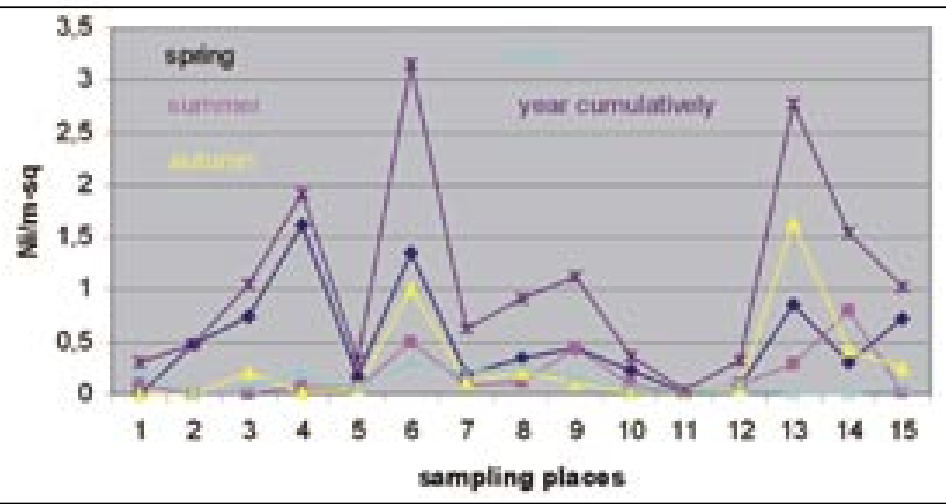

Fig. 13: The dispersion of a phorid species individuals per $m^{2}$ in the Zelezna jama cave, 2000-2001. Sl. 13: Razporeditev osebkov vrste muh grbavk v Železni jami in pred njo, 2000-2001.

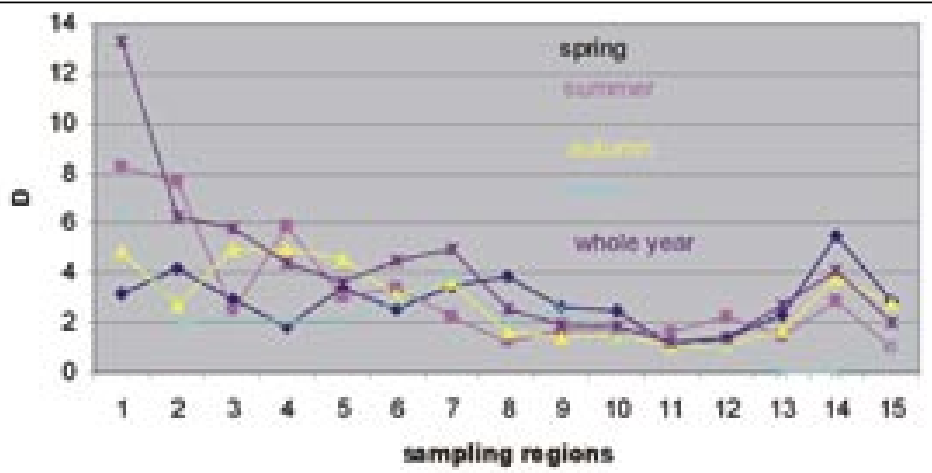

Fig. 14: Simpson's index of dominance, D, in the Železna jama cave, 2000-2001. Sl. 14: Simpsonov indeks dominance, D, v Železni jami, 2000-2001.

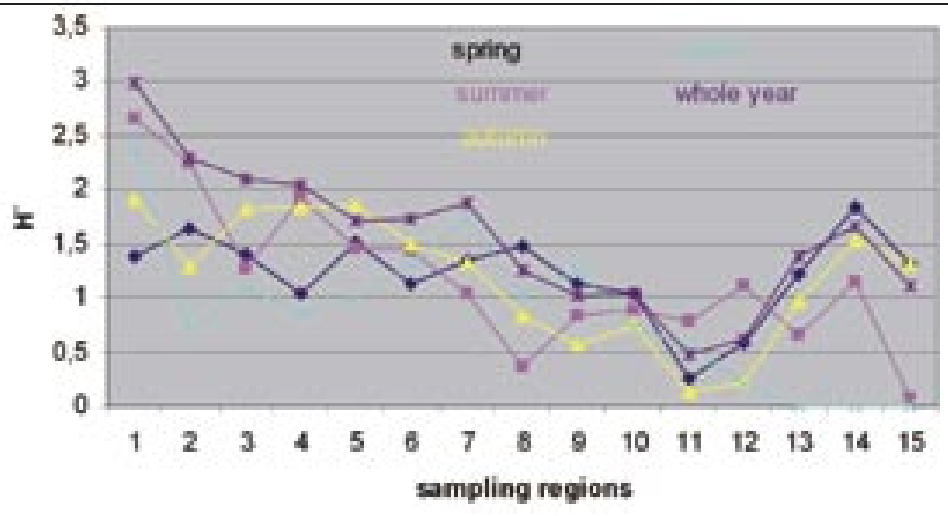

Fig. 15: Shannon-Wiener`s index of diversity, $H$ ', in the Železna jama cave, 2000-2001. Sl. 15: Shannon-Wienerjev indeks diverzitete, H'v Železni jami, 2000-2001. 
sp. and a catopin species, the dipterans Speolepta leptogaster and species belonging to the families Phoridae and Sciaridae.

The troglobitic species were as follows: the snail Zospeum sp., the oniscoid Androniscus sp., the spiders Stalita sp. or Parastalita sp. (escaped) the springtail Onychiurus sp. and the beetles Anophtalmus f. fallaciosus and Ceuthmonocharis $r$. robici.

There are three or four main migration routes between the cave passage on the one hand, and the surface or the inaccessible fissure and water channel. on the other. The first route consists of both entrances and the adjacent sections (pts. 2-6 in Fig. 1). The next one comprises the sections at the bottom of the cave (pts. 8,13-15) in close connection with the inaccessible water channel. The sections 13-15 also reflect a hypothetical continuation (surface opening/s not detected) of the migratory route through the chimney(s) between points 6 and 7. Point 12 is connected with the inaccessible upper fissure system that probably leads to the surface. The diversity indexes are presented in the Figs. 14-15.

\section{Statistical analysis}

All correlations between the distances of sampling sites in the cave from outside habitats, and the diversity indexes were significant; the $\mathrm{H}^{`}$ and $\mathrm{H}^{\prime}$ max declined from the outside towards the inside, while the inverse was true for the D slope (Table 1). Seasonal differences between migratory- and non-migratory cave sections in $\mathrm{H}^{`}, \mathrm{H}$ 'max and $\mathrm{D}$ are presented in Table 2.

The descriptive statistics of diversity for the entire cave are presented in Table 3. Considering the fauna of the entire cave, $\mathrm{H}^{\prime}\left(\mathrm{F}_{(3,52)}=1.84, \mathrm{P}=0.151\right)$ and $\mathrm{D}\left(\mathrm{F}_{(3.52)}=0.03, \mathrm{P}=0.993\right)$ did not differ significantly in between seasons, while the inverse was true in $\mathrm{H}^{\prime} \max \left(\mathrm{F}_{(3.52)}=4.12, \mathrm{P}=0.011\right)$. In the differentiated treatment of migratory- and non-migratory sections, the winter values of $\mathrm{H}^{\prime}\left(\mathrm{F}_{(3,16)}=4.20\right.$, $\mathrm{P}=0.027)$ and $\mathrm{H}^{\prime} \max \left(\mathrm{F}_{(3,16)}=4.08, \mathrm{P}=0.025\right)$ were significantly lower in the migratory cave sections, while there were no differences in $\mathrm{D}\left(\mathrm{F}_{(3,16)}=0.66, \mathrm{P}=0.591\right)$. In the non-migratory parts, there were no statistical differences between seasons in any index: $\mathrm{H}^{\prime}\left(\mathrm{F}_{(3,32)}=0.16, \mathrm{P}=0.925\right), \mathrm{H}^{\prime} \max \left(\mathrm{F}_{(3,16)}=1.91\right.$, $\mathrm{P}=0.148)$ and $\mathrm{D}\left(\mathrm{F}_{(3,16)}=0.22, \mathrm{P}=0.879\right)$ (Tab. 3).

\begin{tabular}{|l|l|l|l|}
\hline & \multicolumn{1}{|c|}{$\boldsymbol{H}$} & \multicolumn{1}{c|}{$\boldsymbol{H}$ 'max } & \multicolumn{1}{c|}{$\boldsymbol{D}$} \\
\hline $\begin{array}{l}\text { polygonal distance from the horizontal } \\
\text { entrance } \\
\text { poligonska oddaljenost od vodoravnega } \\
\text { vhoda }\end{array}$ & $\begin{array}{l}\mathrm{r}=-0.58, \\
\mathrm{P}<0.001\end{array}$ & $\begin{array}{l}\mathrm{r}=-0.41, \\
\mathrm{P}=0.002\end{array}$ & $\mathrm{r}=0.56, \mathrm{P}<0.001$ \\
\hline $\begin{array}{l}\text { polygonal dist. from the nearest } \\
\text { migratory entrance } \\
\text { poligonska odd. od najbližjega } \\
\text { migracijskega vhoda }\end{array}$ & $\begin{array}{l}\mathrm{r}=-0.57, \\
\mathrm{P}<0.001\end{array}$ & $\begin{array}{l}\mathrm{r}=-0.42, \\
\mathrm{P}=0.001\end{array}$ & $\mathrm{r}=0.55, \mathrm{P}<0.001$ \\
\hline $\begin{array}{l}\text { vertical distance from the surface } \\
\text { vertikalna odd. od površja }\end{array}$ & $\begin{array}{l}\mathrm{r}=-0.58, \\
\mathrm{P}<0.001\end{array}$ & $\begin{array}{l}\mathrm{r}=-0.43, \\
\mathrm{P}=0.001\end{array}$ & $\mathrm{r}=0.44, \mathrm{P}=0.001$ \\
\hline
\end{tabular}

Table 1: Pearson's correlation coefficients between the distances of the sampling sites in the Železna jama cave from outside habitats, and H', H'max and D indexes, 2000-2001.

Tabela 1: Personov korelacijski koeficient med oddaljenostjo vzorčevalnih mest v Železni jami od zunanjih habitatov ter indeksi H', H'max in D, 2000-2001. 


\begin{tabular}{|l|l|l|l|}
\hline \multicolumn{1}{|c|}{$\boldsymbol{H}^{\prime}$} & \multicolumn{1}{c|}{$\boldsymbol{H}^{\prime}$ max } & \multicolumn{1}{c|}{$\boldsymbol{D}$} \\
\hline $\begin{array}{l}\text { spring } \\
\text { pomlad }\end{array}$ & $\mathrm{F}_{(1,12)}=5.19, \mathrm{P}=0.042^{*}$ & $\mathrm{~F}_{(1,12)}=19.43, \mathrm{P}=0.001^{*}$ & $\mathrm{~F}_{(1,12)}=1.59, \mathrm{P}=0.231$ \\
\hline $\begin{array}{l}\text { summer } \\
\text { poletje }\end{array}$ & $\mathrm{F}_{(1,12)}=9.65, \mathrm{P}=0.009^{*}$ & $\mathrm{~F}_{(1,12)}=3.44, \mathrm{P}=0.088$ & $\mathrm{~F}_{(1,12)}=10.61, \mathrm{P}=0.007^{*}$ \\
\hline $\begin{array}{l}\text { autumn } \\
\text { jesen }\end{array}$ & $\mathrm{F}_{(1,12)}=1.35, \mathrm{P}=0.269$ & $\mathrm{~F}_{(1,12)}=0.41, \mathrm{P}=0,536$ & $\mathrm{~F}_{(1,12)}=1.21, \mathrm{P}=0.293$ \\
\hline $\begin{array}{l}\text { winter } \\
\text { zima }\end{array}$ & $\mathrm{F}_{(1,12)}=0.71, \mathrm{P}=0.416$ & $\mathrm{~F}_{(1,12)}=0.10, \mathrm{P}=0.756$ & $\mathrm{~F}_{(1,12)}=0.01, \mathrm{P}=0.982$ \\
\hline $\begin{array}{l}\text { whole year } \\
\text { vse leto }\end{array}$ & $\mathrm{F}_{(1,54)}=5.40, \mathrm{P}=0.024^{*}$ & $\mathrm{~F}_{(1,54)}=2.88, \mathrm{P}=0.095$ & $\mathrm{~F}_{(1,54)}=5.23, \mathrm{P}=0.026^{*}$ \\
\hline
\end{tabular}

Table 2: Seasonal differences between migratory-and non-migratory cave sections per season for $H$, H'max and D indexes in the Železna jama cave, 2000-2001(* significant difference at P>0.05).

Tabela 2: Sezonske razlike med migracijskimi in nemigracijskimi deli Železne jame ter indeksi $H$, H'max in D, 2000-2001.

\begin{tabular}{|c|c|c|c|c|c|c|}
\hline & \multicolumn{2}{|c|}{$H^{\prime}$} & \multicolumn{2}{|c|}{$H_{\text {max }}$} & \multicolumn{2}{|c|}{$D$} \\
\hline & Mean & Std.D. & Mean & Std.D. & Mean & Std.D. \\
\hline \multicolumn{7}{|c|}{$\begin{array}{l}\text { Migratory cave sections, } \mathbf{N}=\mathbf{2 0} \\
\text { Migracijski deli jame }\end{array}$} \\
\hline $\begin{array}{l}\text { spring } \\
\text { pomlad }\end{array}$ & 1.183 & 0.537 & 1.783 & 0.285 & 0.453 & 0.261 \\
\hline $\begin{array}{l}\text { summer } \\
\text { poletje }\end{array}$ & 1.391 & 0.298 & 1.711 & 0.218 & 0.310 & 0.107 \\
\hline $\begin{array}{l}\text { autumn } \\
\text { jesen }\end{array}$ & 1.171 & 0.568 & 1.594 & 0.438 & 0.434 & 0.274 \\
\hline $\begin{array}{l}\text { winter } \\
\text { zima }\end{array}$ & 0.443 & 0.350 & 0.888 & 0.715 & 0.544 & 0.358 \\
\hline $\begin{array}{l}\text { whole year } \\
\text { vse leto }\end{array}$ & 1.047 & 0.556 & 1.494 & 0.556 & 0.435 & 0.258 \\
\hline \multicolumn{7}{|c|}{$\begin{array}{l}\text { Non-migratory cave sections, } \mathbf{N}=\mathbf{3 6} \\
\text { Nemigracijski deli jame }\end{array}$} \\
\hline $\begin{array}{l}\text { spring } \\
\text { pomlad }\end{array}$ & 0.711 & 0.250 & 1.142 & 0.248 & 0.594 & 0.161 \\
\hline $\begin{array}{l}\text { summer } \\
\text { poletje }\end{array}$ & 0.752 & 0.399 & 1.451 & 0.266 & 0.633 & 0.204 \\
\hline $\begin{array}{l}\text { autumn } \\
\text { jesen }\end{array}$ & 0.808 & 0.558 & 1.411 & 0.550 & 0.597 & 0.262 \\
\hline $\begin{array}{l}\text { winter } \\
\text { zima }\end{array}$ & 0.668 & 0.533 & 1.007 & 0.653 & 0.540 & 0.319 \\
\hline $\begin{array}{l}\text { whole year } \\
\text { vse leto }\end{array}$ & 0.735 & 0.436 & 1.253 & 0.482 & 0.591 & 0.256 \\
\hline
\end{tabular}

Table 3: Descriptive statistics of H'H'max and D indexes, comparing the migratory- and nonmigratory sections of the Železna jama cave, 2000-2001.

Tabela 3: Opisna statistika indeksov H' H'max in D med migracijskimi in nemigracijskimi deli Železne jame, 2000-2001. 
In the migratory sections, $70.08 \%$ of $\mathrm{H}^{`}$ was realized, and in non-migratory ones $58.66 \%$. The curves of seasonally realized $\mathrm{H}^{`}$ were inverse: the values of $\mathrm{H}^{`}$ were more stable in the non-migratory sections in comparison to the migratory ones (Fig. 16).

\section{Biomass}

The invertebrate biomass (Fig. 17) did not differ between the seasons, either when calculated per entire sampling sections irrespective of their largeness $\left(\mathrm{F}_{3,56}=0.880, \mathrm{P}=0.457\right)$ or when calculated per $\mathrm{m}^{2}\left(\mathrm{~F}_{3,50}=0.931, \mathrm{P}=0.433\right)$.

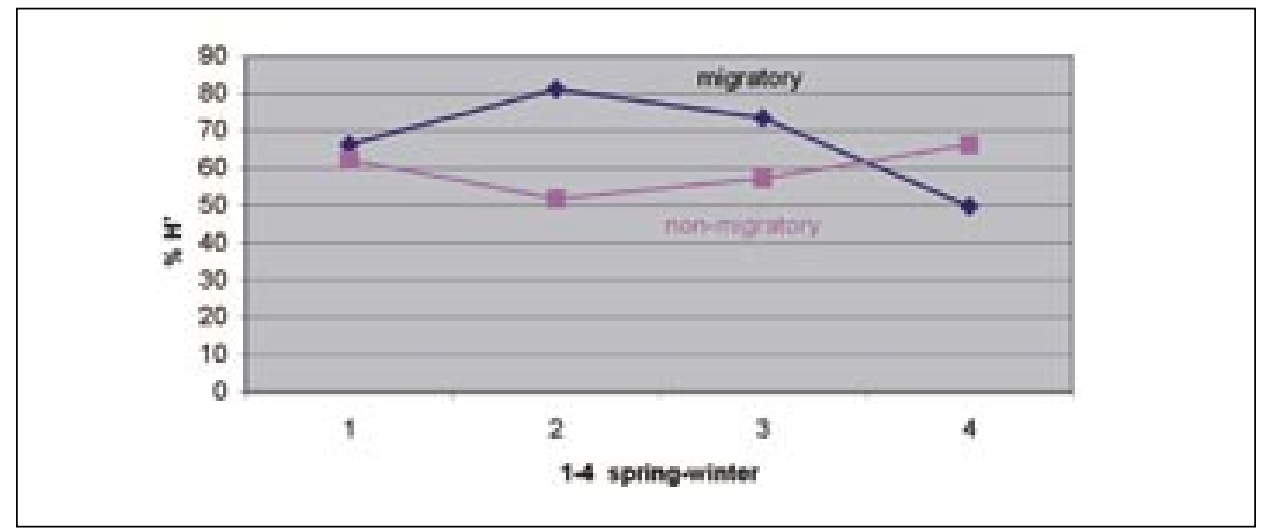

Fig. 16: Shannon-Wiener's diversity index in migratory- and non-migratory sections of the Železna jama cave, 2000-2001.

Sl. 16: Shannon-Wienerjev indeks diverzitete v migracijskih in nemigracijskih delih Železne jame, 2000-2001.

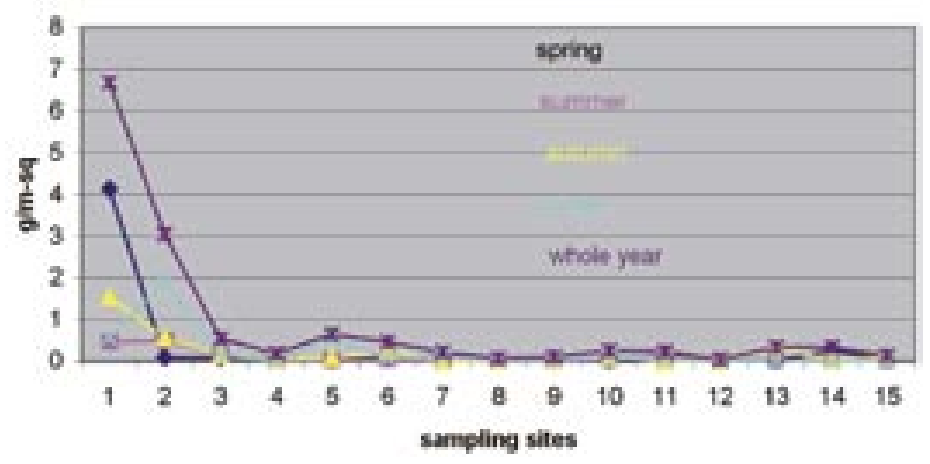

Fig. 17: Invertebrate biomass in the Železna jama cave, 2000-2001.

Sl. 17: Biomasa nevretenčarjev v Železni jami, 2000-2001. 


\section{DISCUSSION}

Drovenik (1972) cited approximately 30 species from the Železna jama cave; in contrast 53 were found during our investigations. The most abundant taxa were the edaphic Ceuthmonocharis and the phorid fly, and the parietal taxa Amilenus, Troglophilus and Limonia. The troglomorphotic taxa were Zospeum, the dysderid spider, Anophthalmus and Ceuthmonocharis. Further species are expected in the cave. If the inaccessible water current to become artificially accessible, some stygobitic species (e.g. the snails Hauffenia erythropomatia, Iglica hauffeni and Paladilhiopsis robiciana), found in springs in the region (Drovenik, 1972), would also be expected. Moreover, some copepod and other epikarstic species can probably be captured in the cave in water seeps and drip pools (cf. Pipan, 2003). Nevertheless, we do not expect further data to affect significantly the general faunal features of the cave.

There are other factors influencing the biotic diversity in the cave. Nevertheless, overall ecological circumstances (T, HR, draught, darkness) are relatively constant in the inner parts of the cave, and their impact on diversity is mostly statistically unprovable. In large part, changes in the diversity are generated by faunal migrations in respect to the adjacent habitats, the migrations being caused by moderate abiotic changes in cave microhabitats. Two faunal groups take part in and share the impact on diversity in the cave, the threshold- and the indigenous hypogean fauna. The first group comprises trogloxene and some troglophilous species migrating seasonally between epigean and cave habitats, and the second one consists of troglobitic and some troglophilous species migrating between the fissure systems and other inaccessible hypogean habitats adjacent to the cave passage. The threshold fauna migrate mostly in response to seasonal changes in the regional and local climate; its taxa are not very sensitive to constant high level of air humidity until they undergo dormancy. On the contrary, the indigenous hypogean fauna need humidity saturated air and mostly avoid droughts. Daily and annual migrations caused by drought are known especially in beetles (Juberthie, 1969; Delay, 1978; Novak et al., 1981; Racovitza, 1983). Major changes in diversity revealed that many microhabitats of the Železna jama cave are within the ecotone zones.

In addition to migrations through both known entrances, there are other terrestrial entrances as evidenced by the presence of the dormice, because these used neither the artificial nor the natural entrance, but some other undiscovered narrow passage(s), thus avoiding the stone martin (cf. Polak, 1997). Further evidence for faunal movements between the cave and other adjacent habitats are trogloxene invasions from the inaccessible water channel at the bottom of the cave. The amphibians that entered the cave obviously overwintered in the channel. In the same way the hygrophilous carabid Agonum scrobiculatum found its way into the cave.

Trogloxene representatives preferred habitats near the surface and the entrances (e.g. Meta), or they migrated using the entrance routes (e.g. Amilenus, Troglophilus, Limonia). Deeper in the cave, the edaphic taxa (e.g. Ceuthmonocharis, Laemosthenes) were most abundant in well structured, moist argillaceous substrate, like gravel with clay and cloddy clay, containing larger amounts of organic matter. Thus they were most abundant in climatically appropriate microhabitats nearest to the surface and the entrances. In this way, in such migratory microhabitats both species groups together increased the diversity.

Juberthie \& Decu (1994) introduced the term "troglobiomorphism" to depict morphological characteristics in troglobites, in place of "troglomorphism" meaning a similarity to caves. Although this criticism is justified, the proposed term "troglobiomorphism" is just another unfortunate termi- 
nology choice because of its redundancy. To qualify the process of morphological response, the term "troglomorphogenesis" would seem to be appropriate, while the terms "troglomorphosis", "troglomorphotic" etc. are perhaps more adequate to qualify the morphological state of an organism.

\section{ACKNOWLEDGEMENTS}

We are very grateful to Mag. Slavko Polak (Postojna) for comments on the hypogean beetles and spiders of the region under investigation. Many thanks to Milan Řezáč (Prague) for the determination of some spiders. We thank Dr. Giulio Gardini (Genova) for comments on Neobisium brevipes. We are indebted the anonymous referee for the insighting remarks on the manuscript, and Dr. Michelle Gadpaille (Maribor) for linguistic improvement.

\section{REFERENCES}

Beier, M., 1939: Die Höhlenpseudoscorpione der Balkanhalbinsel. Studien aus dem Gebiete der allgemeinen Karstforschung, der wissenschaftliche Höhlenkunde, der Eiszeitforschung und den Nachbargebieten. Brün. Biol. Ser. 4, 10: 1-83.

Bohinec, V., 1972: Simon Robič kot jamar. (Simon Robič als Höhlenforscher.) Naše jame, Ljubljana, 13: $12-16$.

Bole, J., 1972: Podzemeljski polži na osamljenem krasu Slovenije. Naše jame, Ljubljana, 13: 5559.

Bole, J., 1974: Rod Zospeum Bourguignant 1856 (Gastropoda, Ellobiiidae) v Jugoslaviji. Razprave SAZU, 4. r., 17/5.

Daffner, H., 1996: Revision der Anophthalmus-Arten und Rassen mit lang und dicht behaarter Körperobersiete. Mitt. München. Entomol. Gesell. 86: 33-78.

Deeleman-Reinhold, C., 1978: Revision of the cave-dwelling and related spiders of the genus Troglohyphantes Joseph (Linyphiidae), with special reference to the Yugoslav species. Opera SAZU, IV. r.

Delay, B., 1978: Milieu souterrain et écophysiologie de la réproduction et du développement des coleoptères bathysciinae hypogées. Mém. Biospéol. NS 5.

Drovenik, B., 1972: O jamski favni Domžal in Moravč. Naše jame, Ljubljana 13: 41-44.

Gams, I., 1972: Železna jama (kat. št. 2678). Naše jame, Ljubljana 13: 27-33.

Gams, I., 1974: Kras. Slovenska matica. Ljubljana.

Ginet, R. \& V. Decou, 1977: Initiation à la biologie et à l’écologie souterraines. Delarge, Paris.

Habe, F., 1972: Nekatere speleološke značilnosti osamljenega krasa Slovenije.Naše jame, Ljubljana 13: 45-53.

Hadži, J., 1930: Prilog poznavanju pećinskih pseudoskorpija. (Contribution à la connaissance des pseudoscorpions cavernicoles). Glas srpske kralj. akad. 140: 3-36.

Jeannel, R., 1924: Monographie des Bathysciinae. Arch. Zool. Éxp. Gén. 64: 1-436.

Joseph, G., 1868: Nachtrag zur Beschreibung von Cyphophthalmus duricorius. Berl. Entomol. Zeitschr., XII.: 269-272. 
Joseph, G., 1881: Erfahrungen im wissenschaftlichen Sammeln und Beobachten der den Krainer Tropfsteingrotten eigenen Arthropoden. Berl. Entomol. Zeitschrift 25, 1-2: 223-282.

Joseph, G., 1882: Systematisches Verzeichniss der in den Tropfstein-Grotten von Krain einheimischen Arthropoden nebst Diagnosen der vom Verfasser entdeckten und bisher noch nicht beschriebenen Arten. Schluss d. Abh.: Erfahrungen im wissenschaftlichen Sammeln und Beobachten der den Krainer Tropfsteingrotten eigenen Arthropoden. Berl. Entomol. Zeitschrift 26, 1: $1-50$.

Juberthie, C., 1969: Relation entre le climat, le microclimat et les Aphaenops cerberus dans la grotte de Sainte-Catherine (Ariège). Ann. spéléol. 24(1): 75-104.

Juberthie, C. \& V. Decu, 1994: Introduction. In: Encyclopaedia biospeologica, 1. Moulis and Bucarest.

Kiauta, B., 1961: Iz zgodovine raziskovanja jam na Moravškem in v okolici Domžal. Proteus 23: 213-216.

Kos, F., 1925: Prirodopisec Simon Robič. Ob stoletnici rojstva (1824-1924). Glasn. Muz. dr. Slov., B, Ljubljana, 4.-6.: 69-77.

Lande, R., 1966: Statistics and partititioning of species diversity, and similarity among multiple communities. Oikos, 76: 5-13.

Novak, T., V. Kuštor, A. Kranjc \& N. Sivec, 1981: Prispevek k poznavanju razporeditve favne v velikih rovih. Acta carsologica 9(6): 149-179.

Novak, T. \& V. Kuštor, 1982: Contribution à la connaissance de la biomasse et du bilan énergétique de la faune des entrées de grotte en Slovénie. Mém. Biospéol. 8: 27-32.

Pipan, T., 2003: Ekologija ceponožnih rakov (Crustacea: Copepoda) v prenikajoči vodi kraških jam. Doct. Dissert., Univ. Ljubljana.

Polak, S., 1997: The use of caves by the edible dormouse (Myoxus glis) in the Slovenian karst. Nat. Croat. 6, 3: 313-321.

Pretner, E., 1959: Rod Ceuthmonocharis Jeannel (Coleoptera, Catopidae). Acta carsologica, 2: 263-284.

Racovitza, G., 1983: Sur la relation dinamiques entre le milieu souterrain superficiel et le milieu cavernicole. Mém. Biospéol. 10: 85-89.

Rakovec, I., 1955: Geološka zgodovina ljubljanskih tal. Zgodovina Ljubljane, 1, z geološko karto ljubljanskega prostora, Ljubljana: $11-207$.

Robič, S., 1862: Über einige Grotten und Höhlen in der Umgebung von Aich. 3. Jahresber. d. Ver. d. krainischen Landes-Museums: 165-167.

Sambol, J. \& T. Novak, 2001: Favna Železne jame. Zbornik ob 40-letnici Društva za razisk. jam Simon Robič: 15-18.

Schmidt, F. J., 1866: Verzeichnis der von mir bisher in Krain aufgefundenen und in meiner Sammlung befindlichen Orthopteren. Mitt. Musealver. Krain, Laibach 1: 77-88.

Stražar, S., 1979: Moravška dolina: življenje pod Limbarsko goro. Moravče.

Stražar, S., 1996: Župnija Dob skozi stoletja. Dob.

Us, P., 1970: Prispevek k poznavanju jamskih ortopterov Jugoslavije (Orthoptera - Tettigonoidea). Acta carsologica SAZU 5: 301-319.

Vandel, A., 1964: Biospéologie. Gauthier-Villars, Paris.

Wolf, B., 1934-38: Animalium cavernarum catalogus. W. Junk. 


\section{DINAMIKA FAVNE V ŽELEZNI JAMI}

\section{Povzetek}

V letih 2000-2001 smo v vsakem letnem času na dveh obiskih v razmaku 48 ur raziskovali favno in ekološke razmere v Železni jami pri Dobu. Jamo smo razdelili na 14 delovnih območij, prvo merilno mesto je bilo pred jamo (slika 1). Opravili smo naslednje meritve: oddaljenost osebkov od vhoda (natančnost: $1 \mathrm{~m})$, velikost preseka rova $\left(1 \mathrm{~m}^{2}\right)$, temperatura zraka in tal $\left(0,1^{\circ} \mathrm{C}\right)$, psihrometrijska zračna vlaga, HR $(1 \%)$, vlaga tal, HY $(0,1 \%)$ in prepih (meritve premikanja megle oziroma dima; $0,1 \mathrm{~m} / \mathrm{s}$ ). Favno smo raziskovali s sistematičnim pregledovanjem sten in stropa do višine 5 $\mathrm{m}, \mathrm{s}$ talnimi pastmi z vabo (razkrajajoče se goveje meso, obešeno nad mešanico sadnega soka in detergenta) ter s presuševanjem talnih vzorcev na modificiranih Tullgrenovih lijakih. Dodatno smo ob vhodu, na sredini in na koncu jame nastavili vzmetne pasti za male sesalce. Biotsko diverziteto smo ocenili z izračunom Simpsonovega (D) ter Shannon-Wienerjevega koeficienta (H') ter ocenili biomaso nevretenčarjev na $\mathrm{m}^{2}$. Korelacije med oddaljenostjo vzorčnih mest od vhoda ter $\mathrm{D}, \mathrm{H}$ in H`max smo izračunali z uporabo Pearsonovega korelacijskega koeficienta. Realizirano H` smo izračunali kot \% glede na H’max. Primerjali smo razlike v diverzitetnih indeksih v migracijskih in nemigracijskih predelih jame.

Železna jama je v speleološkem smislu suha, ekološke razmere so relativno konstantne vse leto. Pozimi so vhodni deli anemodinamični. V jami smo našli 53 taksonov (List 1) iz dveh cenotskih skupin: favne vhodnih delov jam, ki jo predstavljajo (srednje)evropske vrste, pogoste v vhodnih delih podzemeljskih habitatov v vsej (srednji) Evropi, ter endemične hipogejične favne. Kot dominantne smo obravnavali taksone z več kot 50 najdenimi osebki. Ti so: Meta menardi, Amilenus auriantiacus, Troglophilus neglectus, T. cavicola, Laemosthenes schreibersi, Ceuthmonocharis $r$. robici, Limonia nubeculosa in nedoločena vrsta foride. Troglomorfozni taksoni so Zospeum sp., C. r. robici, Anophthalmus $f$. fallaciosus in nekateri drugi.

Sezonske migracije favne potekajo med posameznimi predeli jame ter med jamo in površjem, bližnjimi sistemi špranj in majhnimi, človeku nedostopnimi rovi. Poleg sezonskih sprememb v lokalni klimi so spremembe jakosti prepiha ter količina organskih snovi v substratu v posameznih delih jame verjetno najpomembnejši vzroki za migracije. Živali migrirajo med jamo in površjem, sistemi špranj ob jami ter vodnim rovom ob dnu jame.

Juberthie in Decu (1994) sta za oznako morfoloških značilnosti troglobiontov uvedla izraz "troglobiomorfizem" namesto "troglomorfizem", ker slednji pomeni podobnost z jamami. Zaradi istorečja pa je tudi izraz "troglobiomorfizem" nerodno izbran. Proces morfološkega odziva organizmov na določeno okolje je morfogeneza, na podzemeljsko okolje troglomorfogeneza, za opredelitev morfoloških značilnosti organizmov se zdi zato ustreznejša raba terminov "troglomorfoza", "troglomorfozen" itd. 
